\title{
Subject properties in presentational sentences in Icelandic and Swedish
}

\author{
Annie Zaenen, Elisabet Engdahl \& Joan Maling
}

\begin{abstract}
We review the various non-canonical positions in which the thematically highest argument can occur in Icelandic and in Swedish. We show that NPs in these non-canonical positions have subject properties in both languages. We summarize the restrictions that we are aware of holding on the various positions and discuss whether they are configurational or thematic/semantic in nature.
\end{abstract}

\section{Introduction}

Scandinavian languages are considered to be strongly configurational, meaning that grammatical functions are identified with phrase structure positions. More specifically, in matrix clauses the subject appears either immediately before the tensed verb or immediate following it. We will call these positions canonical subject positions. Although these positions are the most common positions for subjects, it has, of course, been observed that NPs with the same thematic relation to the verb can occur in other positions; this is especially true of the indefinite NPs that occur in presentational constructions. Following e.g. Beaver et al. (2005), we will call these pivots. Discussions of pivots tend to center on the nature of the definiteness constraint. What has been less studied is whether pivots have syntactic subject properties or whether they show more objectlike behavior. In traditional grammar, subjects are defined either by case marking and agreement properties or by positional properties. Under a positional definition of subject, pivots are obviously not subjects. Keenan (1976), however, introduced a distinction between coding properties, behavioral properties and semantic properties which allows for a more nuanced analysis. Older linguistic descriptions focussed on coding properties, but behavioral properties are those that in current linguistic theories are more often seen as being properly syntactic.

In this paper we investigate the degree to which these syntactic properties of pivots are similar to those of canonical subjects in two Scandinavian languages: Icelandic, an insular Scandinavian language, and Swedish, a mainland Scandinavian language. In the first part of the paper we argue that pivots in both languages, even those internal 
to the VP, have syntactic subject properties. In the second part of the paper we show that there are some thematic constraints on these pivots that don't apply to NPs in canonical subject positions. We conclude with a discussion of how the properties we have found might be parcelled out among notions of subject and topic. Some of our findings go against previous research on mainland Scandinavian languages. For Norwegian, it has been claimed that pivots are objects (Askedal 1986; Lødrup 1999; Sveen 1996) and Mikkelsen (2002) makes the same claim for Danish. This has been questioned for Swedish by Börjars and Vincent (2005) and we elaborate here on their findings.

\section{Syntactic subject properties of pivots}

\subsection{Icelandic}

Icelandic is often presented as a configurational language par excellence because it can be shown that non-nominative NPs in the canonical subject positions do pass syntactic subjecthood tests, whereas nominative co-arguments of these NPs that are realized outside of these positions do not have these subject properties (Zaenen et al. 1985; Sigurðsson 2004). In their analysis Zaenen et al. (1985) follow Keenan (1976) in making a distinction between coding and behavioral properties of potential subjects. Coding properties are position, case marking and verb agreement. Behavioral properties are inter alia reflexivization, control and raising. Zaenen et al. (1985) took the behavioral properties as the most interesting from a syntactic point of view, so they called the NP which displayed these properties the subject. They established that in Icelandic these properties did not depend on case marking for derived subjects (more specifically, subjects in passive constructions). Their demonstration was spelled out more extensively for non-derived, basic subjects in active constructions by Sigurðsson (2004). However, Zaenen et al. (1985) as well as Sigurðsson (2004) limited their discussion to NPs in canonical subject position. They showed that these NPs have, over and above their positional characteristics, behavioral properties (control, obligatory reflexivization, raising to object (AcI) and subject ellipsis) that distinguish them from other nominal elements in the sentence, but they did not investigate whether these properties also apply to what we here call pivots. This is the question we address in this paper. Do pivots display the behavioral subject properties listed above or not? We investigate this for Icelandic as we think that the question has never been raised with respect to that language and we compare the results with results for a mainland Scandinavian language. In this article we only investigate Swedish and leave the situation in Danish and Norwegian for future research.

Like many other languages, Icelandic has a presentational construction in which an indefinite NP occurs to the right of the canonical subject positions. Icelandic even has an exceptionally rich variety of positions in which such NPs can occur with different constraints associated with each position. We summarize here the account given in 
Thráinsson (2007, p. 314), who gives the following examples illustrating the various positions.

(1) Dað hafði einhver köttur alltaf verið í eldhúsinu. EXPL had some-NOM cat-NOM always been in kitchen-the 'There had always been some cat in the kitchen.'

(2) Раð hafði alltaf einhver köttur verið í eldhúsinu. EXPL had always some-NOM cat-NOM been in kitchen-the 'There had always been some cat in the kitchen.'

(3) Раð hafði alltaf verið einhver köttur i eldhúsinu. EXPL had always been some-NOM cat-NOM in kitchen-the 'There had always been some cat in the kitchen.'

We also follow Thráinsson (2007) in labeling the pivots in these positions higher intermediate pivot (higher I-pivot), as in example (1), or lower intermediate (lower I-pivot), as in (2), and VP-pivot, as in (3). ${ }^{1}$

There are restrictions on the quantifiers that can occur as determiners in these positions which have been studied in detail in Vangsnes $(1999,2002)$. Furthermore there are restrictions on the types of verbs that allow pivots in the different positions. Thráinsson (2007, p. 310 f.) gives examples of unaccusative and unergative intransitives, passives, middles, transitives and more. We will look first at unergative and transitive verbs. Unergative intransitive verbs of motion allow both I-pivots and VP-pivots whereas transitive verbs only allow I-pivots.

(4) Баð hafa nokkrar rollur hlaupið yfir veginn.

EXPL have-PL some-NOM sheep-NOM run across road-the

'Some sheep have run across the road.'

(5) Раð hafa hlaupið nokkrar rollur yfir veginn.

EXPL have-PL run some-NOM sheep-NOM across road-the

'Some sheep have run across the road.'

(6) Раð hefur einhver stolið hjólinu mínu.

EXPL has somebody-NOM stolen bike mine

'Somebody has stolen my bike.'

1 Note that the higher I-pivot position, immediate after the tensed verb, can be argued to be a canonical subject position. This paper focuses on VP-pivots and we will not discuss whether one should distinguish between the higher I-pivot position and the canonical subject position. 
*־að hefur stolið einhver hjólinu mínu.

EXPL has stolen somebody-NOM bike mine

Intended: 'Somebody has stolen my bike.'

The same pattern seems to obtain with verbs that take an infinitival VP complement; I-pivots are possible, as in (8), but not VP-pivots. This is illustrated with a control verb in (9).

(8) Dað hafa margir reynt að klifa fjallið.

EXPL have many-NOM tried to climb the-mountain

'Many people have tried to climb the mountain.'

(9) *Баð hafa reynt margir að klifa fjallið.

EXPL have tried many-NOM to climb the-mountain

Intended: 'Many people have tried to climb the mountain.'

In the previous examples, the initial position is occupied by an expletive ( $p a ð)$. As is well known, the expletive is restricted to clause-initial position in Icelandic, unlike in the mainland Scandinavian languages. When the tensed verb is in first position, as in yes/no questions, or when a non-subject is topicalized, no expletive shows up, as illustrated in the following examples; compare (10) with (1) and (11) with (6).

(10) Hafði ("pað) einhver köttur alltaf verið $i$ eldhúsinu? had EXPL some-NOM cat-NOM always been in kitchen-the 'Had there always been some cat in the kitchen?'
(11)
$\begin{array}{llllll}\text { Auk } & \text { pess hefur }\left({ }^{*} \text { pað }\right) & \text { einhver } & \text { stolið hjólinu minu. } \\ \text { as-well-as this has EXPL } & \text { somebody-NOM } & \text { stolen bike mine }\end{array}$
'In addition somebody has stolen my bike.'

In the examples given so far, the case of the pivot is nominative, but other cases are possible. The generalization is that the case of the pivot is the same as it would have been in a canonical subject position. The verb reka takes an accusative subject and the pivot is therefore accusative.

(12) Nokkra hvali hefur rekið à land i nótt. several-ACC whales-ACC has driven to land in night

'Several whales have stranded overnight.'
(13) Dað hefur rekið nokkra hvali á land í nótt. EXPL has driven several-ACC whales-ACC to land in night 'Several whales have stranded overnight.'


We now turn to investigating the behavioral properties of the pivots, starting with reflexivization. Whereas objects can in some cases optionally control reflexives, subject control is obligatory in Icelandic. This is what we find in sentences such as (14) and (15) with I-pivots.

Раð hafa fjórir stúdentar týnt hjólunum

EXPL have four-NOM students-NOM lost bicycles-the sínum/ ${ }^{*}$ peirra.

their-REFL/*their-NON-REFL

'Four students have lost their bikes.'

Фаð hafa aldrei fjórir stúdentar týnt hjólunum

EXPL have never four-NOM students-NOM lost bicycles-the

sínum/ $/{ }^{*}$ peirra.

their-REFL $/{ }^{*}$ their-NON-REFL

'Four students have never lost their bikes.'

VP-pivots also control reflexives as shown in the following examples with the unaccusative verb koma. $^{2}$

(16) Раð hafa margir furðufuglar komið hingað $i$ dag með EXPL have many-NOM strange-fellows-NOM come here to day with einkennilegar uppfinningar sínar/* peirra.

peculiar inventions their-REFL/*their-NON-REFL

'Many strange fellows have come here today with their peculiar inventions.'

(17) Раð hafa komið margir furðufuglar hingað $i$ dag með EXPL have come many-NOM strange-fellows-NOM here to day with einkennilegar uppfinningar sínar $/{ }^{*}$ peirra.

peculiar inventions their-REFL/*their-NON-REFL

'Many strange fellows have come here today with their peculiar inventions.'

As the examples show, the reflexivization facts remain the same regardless of the position of the pivot.

The next test concerns subject ellipsis. An active clause with a VP-pivot may be coordinated with a subjectless clause, as shown in (18), provided that the tensed auxiliary is also omitted. This is not possible if the indefinite NP is an object of a transitive verb; then both an overt subject pronoun and a finite verb are required as shown in (19).

2 Examples (16) and (17) are adapted from Rögnvaldsson (1983). 

(18) Раð hafa komið margir furðufuglar hingað i dag og EXPL have come many-NOM strange-fellows-NOM here to day and farið i kröfugönguna.
gone to demonstration-the.

'Many strange fellows have come here today and gone to the demonstration.'
(19) Við höfum hitt marga furðufugla og *(peir hafa) farið we have met many-ACC strange-fellows-ACC and they have gone $i$ kröfugönguna.
to demonstration-the.

Intended: 'We have met many strange fellows and they have gone to the demonstration.'

The pattern shown in (18) has been referred to as 'pseudo-coordination' as it differs in many respects from ordinary coordination (see e.g. Wiklund 2007; Lødrup 2002; Kinn to appear). For our purpose, the label is not important; the difference in grammaticality between (18) and (19) shows that we need to make a distinction between postverbal pivots and objects. ${ }^{3}$

Zaenen et al. (1985) also show that, regardless of case, the understood subject argument of an embedded infinitival clause may be controlled by a subject, or object, in the matrix clause. The verb vanta 'to lack' takes both an accusative subject and an accusative object, see (20). The subject argument may be controlled as shown in (21) from Zaenen et al. (1985):454.

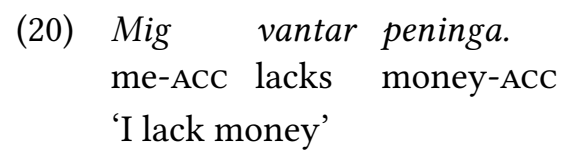

(21) Ég vonast til að vanta ekki peninga.

I hope for to lack not money-ACC

'I hope not to lack money'

However, the infinitival complement of a control verb is not a position in which we expect to find a presentational construction: the pivot would have to be coreferent with the subject or object of the matrix clause. In that case it would no longer be new information, so it does not fullfill the requirements for a presentational construction. Consequently this test is inapplicable to pivots.

The test for subject-to-object raising (also known as Exceptional Case Marking or Accusativus cum Infinitivo), however, reveals some interesting facts. In addition to the expected version in (22), where a subject in canonical position 'exceptionally' receives accusative case (Thráinsson 2007, p. 149), the word order in (23) is also possible.

3 Lødrup (2002, p. 123) actually argues that subject ellipsis is ungrammatical in presentational sentences but his example does not involve pseudo-coordination and has an overt finite verb in the second clause. 
(22)

fón telur hestana hafa verið i kirkjugarðinum.

John believes horses-the-ACC to-have been in churchyard-the

'John believes the horses to have been in the churchyard.'

fón telur ("pað) hafa verið hesta i kirkjugarðinum.

John believes there to-have been horses-ACC in churchyard-the

'John believes there to have been horses in the churchyard.'

As expected, there is no expletive in the embedded clause, but the post-verbal position of the indefinite hesta suggests that this is a presentational structure, as indicated in the paraphrase. It has acquired the accusative case we would expect in an AcI construction, not the nominative, which we would expect when the case is not lexically assigned. ${ }^{4}$ So the pivot seems to have been raised. The situation can be seen as similar to that of backwards raising or control (as discussed in e.g. Polinsky and Potsdam 2012).

There are also passive versions such as (24), or even, although less good, with subject-to-subject raising, as in (25).

$\begin{array}{lll}\text { Раð voru taldir } & \text { vera hestar } & i \\ \text { EXPL were believed-MASC.PL } & \text { to-be horses-NOM-MASC.PL in } \\ \text { kirkjugarðinum } & & \\ \text { churchyard-the } & & \end{array}$

'There were believed to be horses in the churchyard.'

$\begin{array}{lll}\text { ?मаð voru hestar } & \text { taldir } & \text { vera i } \\ \text { EXPL were horses-NOM-MASC.PL } & \text { believed-MASC.PL to-be in } \\ \text { kirkjugarðinum } & & \\ \text { churchyard-the } & & \end{array}$

'There were horses believed to be in the churchyard.'

Notice that in the first of these passives, the matrix verb agrees with the postverbal nominative in the embedded infinitive. We assume a raising analyis for these constructions, but their analysis seems to be very much in flux (see Thráinsson 2007, pp. 452-458 for some discussion).

To summarize, not all tests for subject properties that were used for canonical subjects in Zaenen et al. (1985) are applicable to pivots in Icelandic. But the ones that can be used (reflexivization, subject ellipsis and, arguably, raising) show that pivots behave like subjects.

4 There is evidence from adjuncts that PRO in Icelandic has the case an overt subject would have in a finite clause (Sigurðsson 1991). 


\subsection{Swedish}

With respect to presentational constructions, Swedish differs from Icelandic in two ways. First, I-pivots are not possible, only VP-pivots. Compare the Swedish version of the Icelandic examples in (1)-(3) shown in (26)-(28).

${ }^{*}$ Det hade en katt alltid varit $i$ köket.

EXPL had a cat always been in kitchen-the

'There had always been a cat in the kitchen.'

(27) ${ }^{*}$ Det hade alltid en katt varit $i$ köket.

EXPL had always a cat been in kitchen-the

'There had always been a cat in the kitchen.'

(28) Det hade alltid varit en katt $i$ köket.

EXPL had always been a cat in kitchen-the

'There had always been a cat in the kitchen.'

In periphrastic passive clauses, the pivot typically appears after the auxiliary but in front of a participle which agrees with the pivot. ${ }^{5}$

(29) Det hade blivit så många studenter antagna.

EXPL had become so many students-PL admitted-PL

'There had been so many students admitted.'

Second, the expletive subject is not limited to initial position, but may also occur after the finite verb, e.g. in questions, see (30).

(30) Hade det alltid varit några katter $i$ köket?

had EXPL always been some cats in the-kitchen

'Had there always been some cats in the kitchen?'

Presentational sentences with transitive action verbs (31) and control verbs (32) are impossible, as in Icelandic (7) and (9). ${ }^{6}$

${ }^{*}$ Det har stulit någon student cykeln.

EXPL has stolen some student bike-the

Intended: 'Some student has stolen the bike.'

5 In Danish and Norwegian, the pivot normally follows the participle in such constructions, see Engdahl and Laanemets (2015) and Engdahl (2017). See also Holmberg (2002) for a comparison with Icelandic. 6 In earlier stages, Swedish appears to have been more like Icelandic, allowing I-pivots with transitive verbs (see Håkansson 2017). 
(32)

${ }^{*}$ Det har försökt många att bestiga berget.

EXPL have tried many-NOM to climb mountain-the

Intended: 'Many people have tried to climb the mountain.'

As for case marking, since only pronouns show case in Swedish and personal pronouns are normally not possible in presentational constructions, we wouldn't expect case to show up on the pivot. There is however one construction that allows for a personal pronoun and this can only have nominative case, see (33) from Teleman et al. (1999, Vol. 3 , p. 387). The definite pronoun de together with a relative clause gets a kind reading.

$\begin{array}{llllll}\text { Det lär finnas de } & \text { som fortfarande stöder regeringen. } \\ \text { EXPL MOD exist they-NOM that still } & \text { support government-the }\end{array}$

'There are supposed to be people who still support the government.'

In Swedish, as in Icelandic, clause-internal pronominalization under identity with a subject requires a reflexive, regardless of whether the subject is in canonical position or a VP-pivot, see (34), adapted from Börjars and Vincent (2005).

Det hade kommit en man med $\sin /{ }^{*}$ hans $\quad$ fru.

'There had come a man with his (own) wife.'

With respect to subject ellipsis, active clauses with VP-pivots may be pseudo-coordinated, as observed in Börjars and Vincent (2005) and Engdahl (2006). As in Icelandic, the coordinated verbs must agree in tense and auxiliaries are not repeated. This type of coordination is not possible with objects, see (36).

(35) Det har kommit en student och frågat efter dig. EXPL has come-sup a student and asked-sup after you 'A student has come and asked for you.'

(36) Vi har träffat några studenter och *(de har) frågat efter dig. we have met some students and they have asked-sup after you 'We have met some students and they have asked about you.'

As for the raising-to-object test, the only argument that may raise in Swedish is the overt expletive which is generated in canonical subject position. A Swedish version of the Icelandic example (23) is given in (37).

(37) fohan anser det ha varit för många hästar på John considers ExPL have been too many horses on kyrkogården. churchyard-the 'Johan considers there to have been too many horses in the churchyard.' 
In addition we find examples like (38) where the expletive is a canonical subject of a passive matrix verb. However, (38) is probably best seen as an impersonal passive given that inserting an overt agent phrase such as av Johan 'by Johan' is infelicitous.
Det anses
EXPL consider-PASS have been too many horses on churchyard-the
'It is believed that there have been too many horses in the churchyard.'

Unlike Icelandic, the case of the pivot remains nominative in Swedish. The following example is somewhat stilted, but the pronoun has to be nominative.

Johan anser det omöjligen kunna finnas de
John considers EXPL impossibly can-INF exist they-NOM that
tror att jorden är platt.
believe that earth-the is flat

'Johan considers it impossible that there exist people who believe that the earth is flat.'

We conclude that the reflexivization and subject ellipsis tests show that pivots in Swedish also have syntactic subject properties. But in the AcI construction we see that the expletive also has a syntactic subject property.

\subsection{What identifies subjects in Scandinavian languages?}

It has emerged from the previous discussion that in Icelandic VP-pivots are grammatical subjects under the criteria proposed in Zaenen et al. (1985), whereas the expletive has no subject properties. This leads to the somewhat paradoxical conclusion that in Icelandic, neither case marking nor position uniquely identify subjects. Following Zaenen et al. (1985), Sigurðsson (2004) and others, it seems to have been assumed that position was the relevant coding property since case marking didn't work, but the facts above suggest that this is not generally true. Nor is it an either/or condition, since we can find 'quirky' VP-pivots which also control reflexives, as shown in (40).
Раð hefur að sögn rekið nokkra hvali á land í nótt EXPL has to report driven several-ACC whales-ACC to land in night með kálfum sínum.
with calves their-REFL.
'Reportedly several whales have stranded overnight with their calves.'

In Swedish, the situation is more complicated; reflexivization and pseudo-coordination give the same result as in Icelandic: the pivot behaves as a subject. But the expletive undeniably behaves as a subject in terms of position and raising. ${ }^{7}$

\footnotetext{
7 This is reflected in the terminology used in the reference grammars where both the expletive and the pivot are referred to as subjects. The expletive is commonly referred to as formellt subjekt 'formal subject'. Teleman et al. (1999) refers to the pivot as egentligt subjekt 'real subject' and Faarlund et al. (1997) use the term potensielt subjekt 'potential subject'.
} 
What is then the theoretical status of the canonical subject positions? They are clearly the statistically most prevalent positions in which subjects are found in Icelandic and Swedish, but that is hardly a syntactic distinction. They can also be claimed to be unmarked positions in the sense that all types of subjects can occur in these positions, whereas the other positions are more restricted. But bare non-specific indefinites are, in fact, not very good in the canonical positions. Thráinsson (2007, p.323) gives a question mark to (41).

?Mús hefur verið i baðkerinu.
mouse-NOM has been in bathtub-the
'A mouse has been in the bathtub.'

An indefinite article is required in the corresponding Swedish example in (42), which is grammatical, but somewhat marked compared to a presentational construction.

(42) En mus har varit $i$ badkaret.

a mouse has been in bathtub-the

'A mouse has been in the bathtub.'

Whether these facts are interesting from a syntactic point of view depends on the nature of these constraints: if, as has often been claimed, they are pragmatic in nature (e.g. based on discourse structure), it is not immediately clear that they should be accounted for in syntactic terms.

In the next section we discuss some of the constraints that have been proposed on VP-pivots. While we will not be able to elucidate the nature of these constraints completely, we hope to at least present enough data to provide a good basis for a more substantial study.

\section{Constraints on VP-pivots}

The findings in the previous section go against a widely held belief that the indefinite $\mathrm{NP}$ in presentational sentences in Scandinavian languages is an object (see e.g. Lødrup 1999). But it is not the case that any indefinite subject can occur in the non-canonical positions. As shown in Vangsnes $(1999,2002)$ there are constraints on which quantifiers are possible, summarized in Thráinsson (2007). Another source of constraints is the thematic relation between the verb and its subject argument. These were first discussed in Platzack (1983), who assumed that what we are here calling I-pivots and VP-pivots are generated in different positions, I-pivots outside the VP and VP-pivots inside the VP. In addition he proposed a correlation between syntactic positions and the types of theta roles that can be generated there. ${ }^{8}$ Maling (1988) elaborated on Platzack's analysis and argued that grammatical rules need to refer both to thematic roles and to the

8 In later work, Platzack (2010) has made this connection explicit, referring to the Uniformity of Theta Assignment Hypothesis (UTAH) of Baker (2006). 
mapping between the thematic hierarchy and the syntactic hierarchy. Lødrup (1999) assumed that the VP-pivot is an object, albeit an atypical one since it may have agentive properties, whereas Faarlund et al. (1997) point out certain differences between VP-pivots of active sentences and objects. In this section we take a closer look at the interaction between position and thematic properties.

\subsection{Icelandic}

In Icelandic, subjects of all lexical semantic verb types seem to be possible as I-pivots but not as VP-pivots. We have already seen that the agent argument of a typical active transitive verb cannot occur inside the VP, cf. (7). However, this does not seem to be linked to the transitivity of the verb, as proposed in the analysis by Platzack (1983), since our informants prefer I-pivots also with intransitive verbs with agentive subjects like hringa 'phone', as shown in (43) and (44).

(43) Раð hafði margt fólk hringt i mig i gær.

EXPL had many-NOM people-NOM phoned to me on yesterday

'Many people had phoned me yesterday.'

(44) ?Раð hafði hringt margt fólk i mig i gær.

EXPL had phoned many-NOM people-NOM to me on yesterday

'Many people had phoned me yesterday.'

Similarly, experiencer arguments are acceptable as I-pivots, but not as VP-pivots.

(45) Раð hefur mörgum börnum verið kalt.

EXPL have many-DAT children-DAT been cold.

'Many children have been cold.'

(46) *Баð hefur verið mörgum börnum kalt.

EXPL have been many-DAT children-DAT cold.

'Many children have been cold.'

The goal or recipient argument of hjálpa 'help' is fine as an I-pivot, but not as a VPpivot.

(47) Раð var gömlum manni hjálpað yfir götuna.

EXPL was old-DAT man-DAT helped across street-the

'An old man was helped across the street.'

(48) ?*Рað var hjálpað gömlum manni yfir götuna.

EXPL was helped old-DAT man-DAT across street-the

'An old man was helped across the street.' 
Maling (1988) shows that it is not the case marking but the thematic role that is relevant in these examples. What seems to be at issue is how thematic roles are mapped onto syntactic positions. ${ }^{9}$ Maling demonstrates that whereas it is impossible to realize indefinite experiencer subjects as VP-pivots, as shown in (49), it is possible to find theme subjects with the few verbs that have a theme subject and an experiencer object, as in (50).

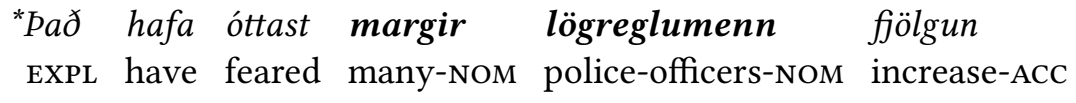

*Dað hafa óttast margir lögreglumenn fjölgun

EXPL have feared many-NOM police-officers-NOM increase-ACC slysa. accidents-GEN

Intended: 'Many police officers feared an increase in accidents.'

(50) Раð hefur hraett einhver mynd börnin.
EXPL has frightened some-NOM picture-NOM children-the-ACC
'Some picture has frightened the children.'

It is clear then that the constraint is not against having two NPs in the VP - given the existence of ditransitive verbs in Icelandic such a constraint would be rather astonishing - but needs to be stated in semantic/thematic terms. We can summarize the findings for Icelandic as follows: I-pivots can occur with all kinds of thematic roles but VP-pivots are only possible with themes. A more precise statement of the constraints, however, needs further research.

Faarlund et al. (1997, p. 846 f.) claim that in Norwegian VP-pivots in active clauses behave differently from VP-pivots in passive clauses. Using reflexivization and coordination tests, they show that only the pivots in active clauses have the typical subject properties identified in Section 2. However, applying their tests to Icelandic gives somewhat different results. ${ }^{10}$ The VP-pivot of a passive verb still controls reflexives, as shown in (51).

(51) Раð var fleygt nokkrum stúdentum út af skrifstofum

EXPL was kicked some students out of office

sinum/??peirra.

their-REFL/NON-REFL

'Some students were kicked out of their offices'

9 Examples (45)-(50) are from Maling (1988).

10 Faarlund et al. (1997) use a third test involving control of adjuncts. We found that while this distinguishes between canonical subjects and pivots in passive clauses, it did not reliably distinguish between pivots in active and passive clauses. 
As for coordination, a passive clause with a VP-pivot may be conjoined with a passive VP, without subject and auxiliary, as in (52). Subject ellipsis in (53) with an active VP in the second conjunct is ungrammatical. ${ }^{11}$

$\begin{array}{lllll}\text { Раð hafa verið } & \text { seldir } & \text { margir } & \text { bílar } & \text { og } \\ \text { EXPL have been } & \text { sold-MASC.PL many-NOM } & \text { cars-NOM-MASC.PL and } & \text { and } \\ \text { fluttir } & & \text { út til Póllands. } & & \\ \text { exported-MASC.PL } & \text { out to Poland } & \end{array}$

'There have been many cars sold and exported to Poland.'

(53) Раð var fleygt nokkrum stúdentum út af skemmtistaðnum

EXPL was kicked several-DAT students-DAT out of nightclub-the og *(peir) urðu æstir.

and they were upset

Intended: 'Several students were kicked out of the nightclub and they were upset.'

In Icelandic, VP-pivots in passive clauses thus show mixed properties. They control reflexivization, like canonical subjects, but are less acceptable in coordination than VP-pivots in active clauses. In addition there is an interaction between thematic roles and the passive, as shown in Maling (1988).

\subsection{Swedish}

We will distinguish between intransitive and transitive constructions. We first note that, with intransitive predicates, Swedish, unlike Icelandic, allows VP-pivots with verbs that normally are interpreted as having agentive subjects as described by e.g. Anward (1981) and Teleman et al. (1999, Vol. 3, p. 400 f.).

(54) Det brukade arbeta många människor här. EXPL used-to work many people here 'Many people used to work here.'

(55) Det har sjungit några islänningar $i$ vår kör. EXPL have sung some Icelanders in our choir 'Some Icelanders have sung in our choir.'

Anward (1981, p. 10) points out that the activity meaning tends to fade away and that the location of the activity is foregrounded when these verbs are used in presentational sentences. He cites as evidence the fact that adding an intentional subject-oriented adverb is infelicitous, see (56). According to Teleman et al. (1999, Vol. 3, p. 400), the

11 Both these examples involve ordinary coordination; see also Eythórsson (2008, p. 179 f.), who discusses similar examples. 
verbs tend to denote activities which are typical in some location or context, such as singing in a choir. They note that it would be strange to emphasize the manner, see (57).

(56) Det har (" ${ }^{*}$ motvilligt) arbetat många människor (" ${ }^{*}$ motvilligt) här. EXPL has reluctantly worked many people reluctantly here Intended: 'Many people have reluctantly worked here.'

$\begin{array}{cllllll}\text { ?Det har sjungit några } & \text { islänningar entusiastiskt } i \text { vår kör. } \\ \text { EXPL have sung many Icelanders enthusiastically in our choir }\end{array}$

Intended: 'Many Icelanders have sung enthusiastically in our choir.'

However, verbs like ringa 'phone', which don't seem to require a location in the presentational construction, can also be used, as shown in (58).
Det har ringt nån till dig.
EXPL has phoned someone to you
'Someone has phoned you.'

But here too the focus seems to be on the event, that there was a phone call, not on the agentivity of the caller. ${ }^{12}$ Recall that our Icelandic informants prefer the I-pivot version of this example, see (43) and (44), but this option is of course not available in Swedish.

Example (59), adapted from Maling (1988), shows that with intransitive verbs, an experiencer argument cannot be realized as a VP-pivot, which we have seen is impossible also in Icelandic, see (45)-(48).

*Det hade frusit några barn i natt.
EXPL had frozen some children in night

Intended: 'Some children had felt cold last night.'

We note in passing that verbs taking experiencer subjects are fine when pseudocoordinated with a presentational clause, see (60).

(60) Det hade suttit några barn utanför och frusit.

EXPL had sat some children outside and frozen

'Some children had sat outside and felt cold.'

This suggests that whatever the constraint against indefinite experiencers is, it only applies to VP-pivots. Once such an indefinite NP has been introduced in the first conjunct, it seems to provide an antecedent for subject ellipsis in the second conjunct. ${ }^{13}$

12 Lødrup (2002, p. 122) notes that communication verbs like ringe 'call' are fine in Norwegian presentational constructions.

13 We now have an explanation for the observation made in Engdahl (2006, p. 41), viz. that it is possible to add an adverb like motvilligt 'reluctantly' in a follow-up clause to a presentational sentence with arbeta 'work'. This is because the presentational sentence introduces a referent which can be referred to in a later clause, essentially the same explanation as for why experiencer verbs are possible in second conjuncts, as in (60). 
Passive verbs allow a goal subject to be realized as a VP-pivot in Swedish, see (61), unlike Icelandic where only the I-pivot is acceptable, as shown in (47) and (48).
(61) Det har hjälpts
tusentals flyktingar
i det här lägret.
EXPL have help-PAss thousands refugees in this camp-the
'Thousands of refugees have been helped in this camp.'

But experiencer subjects of passive verbs are unacceptable as VP-pivots.
(62) ?*Det har skrämts
många barn med berättelser om
EXPL has frightened-PAss many children with stories about
tomten.

Santa-Claus-the

Intended: 'Many children have been frightened with stories about Santa Claus.'

As already observed in Maling (1988, p. 180), there is a difference between Icelandic and Swedish regarding the mapping between thematic roles and syntactic positions: Icelandic has a choice between I-pivots and VP-pivots. Agents, goals and experiencers, which are unacceptable as VP-pivots, are fine as I-pivots in that language. Swedish, having only one pivot position, seems to relax the thematic constraint so that agents can fill this position in intransitive actives and goals in passives, whereas experiencers are unacceptable.

In transitive constructions, as we already mentioned, Swedish does not allow VPpivots with agentive verbs like steal, as shown in (31), repeated here as (63).

$$
\begin{aligned}
& { }^{*} \text { Det har stulit någon student cykeln. } \\
& \text { EXPL has stolen some student bike-the }
\end{aligned}
$$

Intended: 'Some student has stolen the bike.'

We do, however, find presentational sentences with two NPs inside the VP, as already pointed out in Platzack (1983). The following examples are adapted from his article. ${ }^{14}$ In these examples, the pivot is clearly non-agentive, arguably a theme.

Det hade hänt honom något konstigt igår.

ExPL had happened him something strange yesterday

'Something strange had happened to him yesterday.'

(65) Det kunde vänta mig en verklig överraskning när jag kom

EXPL could await me a real surprise when I came

hem.

home

'A real surprise could be waiting for me when I came home.'

14 Platzack's examples have single finite verbs and could be analyzed as involving some form of object shift, as pointed out by an anonymous reviewer. 
Passive versions of ditranstive verbs provide another context where there is more than one NP inside the VP. Example (66) is also adapted from Platzack (1983). Note that the VP-pivot can only realize a theme argument, not a goal argument.

(66) Det hade tilldelats studenten en belöning.

EXPL had given-PAss student-the an award

'The student had been given an award.'

(67) *Det hade tilldelats en student belöningen.

EXPL had given-PASS a student award-the

Intended: 'The award had been given to a student.'

However, we don't find any good Swedish counterparts to the Icelandic themeexperiencer example in (50) despite the possibility of examples like (64)-(65).

(68) *Det hade skrämt barnen nån bild.

EXPL had frightened children-the some picture

Intended: 'Some picture had frightened the children.'

It may be that (68) is impossible because the Swedish verb skrämma 'frighten' is more strongly agentive, or causative, than e.g. hända 'happen', since skrämma is also used with animate subjects, unlike hända. So in Swedish too, only theme VP-pivots are possible when there is another NP argument in the VP.

We now turn to the possible syntactic differences between VP-pivots in active and passive clauses. As for reflexivization, the overall pattern is the same as in Icelandic with VP-pivots preferably controlling reflexive pronouns in passive clauses (69), but there seems to be more variation in Swedish than in Icelandic (cf. Teleman et al. 1999, Vol. 3, p. 394). The opposite preference shows up when the antecedent is an ordinary object, as in (70).

(69) Det hade körts ut några studenter från sina/?deras

EXPL had kick-PASS out some students from their-REFL/NON-REFL

kontor.

offices

'There had been some students kicked out of their offices.'

(70) Man hade kört ut några studenter från deras/?sina

Someone had kicked out some students from their-NON-REFL/REFL

kontor.

offices

'Someone had kicked out some students from their offices.' 
The coordination test also gives the same result for Swedish as for Icelandic. Coordination of two passive VPs is possible, see (71), but when the second conjunct is active, an overt subject pronoun is required as shown in (72).
(71) Det har sålts
många bilar och exporterats
till Polen.
EXPL has sold-PAss many cars and exported-Pass to Poland
'There had been many cars sold and exported to Poland.'
(72) Det hade körts ut några studenter och *(de) var
EXPL had kicked-PAss out some students and they were
upprörda.
upset

'There had been some students kicked out and they were upset.'

Swedish then is similar to Icelandic in that (typical) experiencers are not realized as VP-pivots. As for agents, we find two differences. In Icelandic, agents of transitive verbs can be realized as I-pivots, but this option is not available in Swedish. Agentlike arguments of intransitives are acceptable as VP-pivots in Swedish, but there is a constraint against subject-oriented intentional adverbs and manner adverbs. This constraint suggests that the agentivity of the subject argument is somehow reduced in the presentational construction. It is, however, difficult to pin down what exactly that means. It is unlikely that these agents cannot be seen as having volition; it seems more plausible that the construction does not single out the pivot itself but instead introduces an event, or a situation, as a whole. ${ }^{15}$ Our investigation also confirms that in Swedish, as in Icelandic, the constraint is not on the number of positions in the VP but rather on which thematic roles can be realized there.

\subsection{Position versus thematic roles}

In previous sections we have shown that both position and thematic roles matter when it comes to accounting for what subject properties the pivots in presentational sentences have. In Icelandic, we need to distinguish I-pivot positions from VP-pivot positions since there are more restrictions on the latter. For instance, subjects of transitive verbs cannot occur there, see (7), nor can goals or experiencers, regardless of whether the verb is intransitive, see (45) and (46), or transitive, see (49). In Swedish the intermediate non-canonical subject positions are not available, see (26)-(28). Agentive intransitives are possible but agentive transitive verbs are excluded, see (31) and (32). We find partly similar thematic restrictions on subjects inside the VP as in Icelandic; experiencer pivots are excluded but goals are possible.

Whereas VP-pivots of active verbs behave much like subjects in canonical positions - they control reflexives and allow subject ellipsis in a pseudo-coordinated VP - VPpivots in passive clauses control reflexives but don't allow subject ellipsis, see (53) and 
(72). In this respect they behave more like ordinary objects. This constraint on passives might come as a surprise. But a bit of reflection makes it less surprising: the pivot in the passive case is not the 'logical' subject. Passivization is an argument promotion operation, whereas the presentational construction demotes that same argument. The passivization strategy in the presentational sentences ends up demoting an argument which has already been promoted. It seems that this Duke of York gambit meets with ambivalence in the Scandinavian languages. While this might make intuitive sense, further study is needed of the conditions on both the passive and the presentational construction and of the mechanics that would make such a constraint on the argument mapping possible.

\section{Conclusion}

In this paper we have discussed whether VP-pivots in Icelandic and Swedish have syntactic subject properties. The only explicit discussion of a similar topic that comes to mind is that in Bonami et al. (1999) who discuss Stylistic Inversion for French and contrast a set of subject and object properties for the post-verbal NPs in that language. We have shown that the status of the indefinite NP in presentational constructions in Scandinavian languages is less clear than has been claimed in the literature about Norwegian. In both Swedish and Icelandic, these NPs have syntactic subject properties, even when they occur in VP-complement positions. In Icelandic, we find a rather neat partition of the subject properties that Keenan (1976) called coding properties and behavioral properties: only canonical subjects have the positional coding properties, whereas pivots share the behavioral properties with them. This brings to mind observations made by several authors (see e.g. Lambrecht 1994, pp. 131-145), that subjects tend to be unmarked topics. Under this view, the positional coding properties are actually properties of topics, not of subjects per se.

Present-day Swedish differs from Icelandic in having an expletive that clearly has the same coding properties as canonical subjects. The expletive also behaves like a subject in subject to object raising. So, in this language, there is no neat line-up of the properties following Keenan's (1976) classification together with the hypothesis that the positional properties are topic properties. However, in earlier stages of Swedish, the position of the expletive was more similar to the situation in present-day Icelandic (see Håkansson 2017), which suggests that one should look at the diachronic development as well. One further similarity between Icelandic and Swedish is that the VP-pivot shows nominative case, see (33). ${ }^{16}$ This distinguishes Icelandic and Swedish from Danish and Norwegian where the pivot has been claimed to be accusative (see Mikkelsen 2002; Lødrup 1999). It remains to be seen whether this morphological difference correlates with differences in the syntactic subject properties that are the topic of this paper.

Unless the Icelandic verb has a lexically selected case as in (13). 


\section{Acknowledgments}

For the Icelandic data in this paper we have consulted four native speakers. We thank Einar Freyr Sigurðsson, Halldór Ármann Sigurðsson, Jóhannes Gísli Jónsson and Sigríður Sigurjónsdóttir for their help. Some Swedish judgments were checked with five other speakers and the remainder reflect the intuitions of the Swedish co-author. We also acknowledge the comments from three anonymous reviewers.

\section{References}

Anward, Jan (1981). Functions of passive and impersonal constructions. A case study from Swedish. Ph.D. dissertation, Uppsala University.

Askedal, John Ole (1986). "Ergativity in Modern Norwegian”. In: Nordic fournal of Linguistics 9, pp. 25-45.

Baker, Mark (2006). "Handbook in generative syntax: Elements of grammar". In: Thematic roles and syntactic structures. Ed. by Liliane Haegeman. Dordrecht: Kluwer, pp. 73-137.

Beaver, David, Itamar Francez, and Dmitry Levinson (2005). "Bad subject: (Non-)canonicality of NP distribution in Existentials”. In: SALT XV, pp. 19-43.

Bonami, Olivier, Danièle Godard, and Jean-Marie Marandin (1999). "Constituency and word order in French subject inversion". In: Constraints and resources in natural language syntax and semantics. Ed. by G. Bouma, E. Hinrichs, G.-J. Kruijff, and R. Oehrle, pp. 21-40.

Börjars, Kersti and Nigel Vincent (2005). "Position versus function in Scandinavian presentational constructions". In: Proceedings of the LFG05 Conference. Ed. by Miriam Butt and Tracy King. CSLI, pp. 54-72.

Engdahl, Elisabet (2006). "Semantic and syntactic patterns in Swedish passives". In: Demoting the agent: Passive, middle and other voice phenomena. Ed. by Benjamin Lyngfelt and Torgrim Solstad. Amsterdam/Philadelphia: John Benjamins Publishing Company, pp. 21-45.

- (2017). "Expletive passives in Scandinavian - with and without objects". In: Order and structure in syntax II: Subjecthood and argument structure. Ed. by Laura Bailey and Michelle Sheehan. Language Science Press, pp. 291-308.

Engdahl, Elisabet and Anu Laanemets (2015). "Opersonlig passiv i danska, norska och svenska - en korpusstudie”. In: Norsk Lingvistisk Tidsskrift 33, pp. 129-483.

Eythórsson, Thórhallur (2008). "The New Passive in Icelandic really is a passive". In: Grammatical Change and Linguistic Theory: The Rosendal Papers. Ed. by Thórhallur Eythórsson. Amsterdam/Philadelphia: John Benjamins Publishing Company, pp. 173-219.

Faarlund, Jan Terje, Svein Lie, and Kjell Ivar Vannebo (1997). Norsk referansegrammatikk. Oslo: Universitetsforlaget. 
Håkansson, David (2017). “Transitive expletive constructions in Swedish”. In: Nordic Journal of Linguistics 40(3).

Holmberg, Anders (2002). "Expletives and Agreement in Scandinavian Passives". In: fournal of Comparative Germanic Linguistics 4, pp. 5-128.

Keenan, Edward (1976). "Towards a universal definition of subject". In: Subject and Topic. Ed. by Charles Li. Academic Press, pp. 303-333.

Kinn, Torodd (to appear). "Asymmetric verb phrase coordination in Norwegian. Degrees of grammaticalization and constructional variants". In: Grammaticalization meets Construction Grammar. Ed. by Evie Coussé, Peter Andersson, and Joel Olofsson. Amsterdam: John Benjamins.

Lambrecht, Knut (1994). Information structure and sentence form. Cambridge University Press.

Lødrup, Helge (1999). "Linking and Optimaility in the Norwegian Presentational Focus Construction”. In: Nordic fournal of Linguistics 22, pp. 205-230.

- (2002). "The syntactic structures of Norwegian pseudocoordinations". In: Studia Linguistica 56, pp. 121-143.

Maling, Joan (1988). "Variations on a theme: Existential sentences in Swedish and Icelandic". In: McGill Working Papers in Linguistics, pp. 168-191.

Mikkelsen, Line (2002). "Reanalyzing the Definiteness Effect: Evidence from Danish". In: Working Papers in Scandinavian Syntax 69, pp. 1-75.

Platzack, Christer (1983). "Existential sentences in English, Swedish, German and Icelandic". In: Papers from the seventh Scandinavian Conference of Linguistics. Ed. by Fred Karlsson, pp. 80-100.

- (2010). Den fantastiska grammatiken. En minimalistisk beskrivning av svenskan. Stockholm: Norstedts.

Polinsky, Maria and Eric Potsdam (2012). "Backward Raising”. In: Syntax 15, pp. 75108.

Rögnvaldsson, Eiríkur (1983). "Sagnliðurinn í íslensku”. In: Íslenskt mál 5, pp. 7-28.

Sigurðsson, Halldór Ármann (1991). "Icelandic case-marked PRO and the licensing of lexical arguments". In: Natural Language and Linguistic Theory 9, pp. 327-363.

- (2004). "Icelandic non-nominative subjects: Facts and implications". In: Nonnominative Subjects Vol.2. Ed. by P. Bhaskararao and K.V. Subbarao, pp. 137-159.

Sveen, Andreas (1996). Norwegian Impersonal Actives and the Unaccusative Hypothesis. Dr.art. thesis, University of Oslo.

Teleman, Ulf, Staffan Hellberg, and Erik Andersson (1999). Svenska Akademiens grammatik. Stockholm: Norstedts.

Thráinsson, Höskuldur (2007). The Syntax of Icelandic. Cambridge: Cambridge University Press.

Vangsnes, Øystein (1999). The identification of functional architecture. Doctoral Dissertation, University of Bergen. 
- (2002). "Icelandic expletive constructions and the distribution of subject types". In: Subjects, Expletives, and the EPP. Ed. by Peter Svenonius. Oxford: Oxford University Press, pp. 43-70.

Wiklund, Anna-Lena (2007). The Syntax of Tenselessness. Berlin: Mouton de Gruyter.

Zaenen, Annie, Joan Maling, and Höskuldur Thráinsson (1985). "Case and grammatical functions”. In: Natural Language and Linguistic Theory 3.4, pp. 441-483. 